\title{
ДОТРИМАННЯ КОНВЕНЦІї ПРО ЗАХИСТ ОСНООПОЛОЖНИХ ПРАВ ТА СВОБОД ПЦДУДНИХ В УМОВАХ ТРИМАННЯ У СКЛЯНИХ «БОКСАХ» В СУДАХ
}

\author{
СМУШАК Діана Романівна - студентка магістратури Національного \\ юридичного університету імені Ярослава Мудрого \\ ORCID:0000-0001-8506-4385 \\ УДК 341.231.145 \\ DOI 10.32782/EP.2021.2.26
}

\begin{abstract}
В данной статье рассматривается проблемнъий вопрос относительно условий держания подсудимых в «стеклянных боксах» в зале судебного заседания, собственно соответствие такого держания статьи 3 Конвенции о защите прав и основополагающих свобод человека(дальше - СКПЛ), которьии закрепляет запрет истязания или других видов нечеловеческого или такого, которое унижает достоинство, поведение или наказание. Бъла предоставлена характеристика металлических «клеток» и стеклянных «боксов» и установлено, отвечает ли держание у них правам человека относительно обеспечения непрерьвного общения подсудимого со своим зашитником. Проанализировань ключевые решения ЕСПЛ, в которых было установлено, - какое держание в «боксе» имеет унизительнъий характер. Бълли приведенъг условия, при которьхх держание лич, в «боксах» не является нарушением конвениионных положений. При этом, подчеркнута позитивная сторона направления Украинъ относительно въпполнения - рекомендаций ССП с изелью недопущения нарушений прав человека относительно условий держания в зале суда.

Ключевъе слова: запрет пьток и других видов бесчеловечного или унижающего достоинство обращения или наказания,содержания подсудимьх, “стекляннъе боксыл", решения и позииии ЕСПЧ.
\end{abstract}

Постановка проблеми

На національному рівні - у ст. 3 Конституції України [13] закріплено, що людина, iї життя і здоров'я, честь і гідність, недоторканність і безпека $\epsilon$ найвищою соціальною цінністю. У свою чергу, на міжнародно-правовому рівні - у ст. 1 Загальної декларації прав людини визначено, що всі люди народжуються вільними і рівними у своїй гідності та правах [9]. Україна, ратифікувавши 17.07.1997 р. Конвенцію про захист основоположних прав та свобод людини (далі - Конвенцію), взяла на себе зобов'язання забезпечувати права, гарантовані положеннями Конвенції, проте на практиці нерідко держава порушує права своїх громадян. Зокрема, тримання підсудних під час судового засідання в металевих «клітках» визнавалося $6 С П \lambda$, зокрема, у рішеннях «Свинаренко та Сляднев проти Росії, «Валюжевич проти Росії», «Іващенко проти України» та в інших, порушення статті 3 Конвенції - нелюдським, таким, що принижує гідність, поводженням. На сьогодні ці клітки поступово замінюються «скляними боксами», проте питання, чи не $\epsilon$ вони порушенням права, гарантованого Конвенцією на заборону катування, залишається актуальним.

Аналіз останніх досліджень і публікацій

В Україні на сьогодні питання щодо утримання підсудних у «скляних клітках» $\varepsilon$ не досить дослідженим. Деякі науковці роблять спроби аналізувати цю проблематику, серед них: Червяцова А.О., Попелюшко В.О., Півень А.В., проте все ж вагому роль віді- 


\section{Міжнародне право}

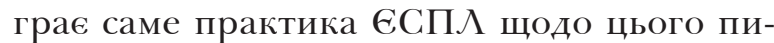
тання.

\section{Постановка завдання}

Головним завданням роботи є вирішення питання щодо того, чи є тримання підсудних у «скляних боксах» порушенням їхніх прав, а саме: чи є нелюдським, таким, що принижує гідність, поводженням крізь призму аналізу практики ССП $\curlywedge$ щодо цього.

\section{Виклад основного матеріалу}

Ст. 3 Конвенції регламентує, що «жодна людина не може зазнавати катувань чи нелюдського або такого, що принижує іiі гідність, поводження чи покарання» [12].

Заборона катувань чи інших видів нелюдського або такого, що принижує гідність, поводження чи покарання, виступає правом i, одночасно, гарантією таких невід'ємних прав людини, якими є право на життя, свободу та особисту недоторканість, право на повагу честі й гідності. Враховуючи значення ст. 3 Конвенції для забезпечення нормального існування особистості та суспільства, ЄСП $А$ неодноразово наголошував на тому, що ця стаття охороняє одну з фундаментальних цінностей демократичного суспільства (рішення у справі «ภабіта проти Італії»), що ця норма має загальне міжнародне визнання, адже вона знайшла своє відображення і в універсальному міжнародно-правовому акті - у ст.5 Загальної декларації прав людини. EСПЛ зазначає, що заборона катувань є «абсолютною, незалежно від попередньої поведінки потерпілого» (рішення у справі «Сьорінг проти Сполученого Королівства») [4], і що «потреби слідства не можуть вести до обмеження захисту фізичного стану людини» [6].

До прийняття нового Кримінальнопроцесуального Кодексу 12.04.2012 р. місця для тримання підсудних у залі судового засідання обладнувалися стаціонарними металевими огородженнями, які відокремлювали їх від складу суду та осіб, які присутні у залі судових засідань. Проте, - такий порядок не узгоджувався 3 вимогами Загальної декларації прав людини, яку
Україна ратифікувала у 1977 році, власне ст.5 закріплює: «ніхто не повинен зазнавати тортур, або жорстокого, нелюдського, або такого, що принижує його гідність, поводження і покарання» [9], Конвенцією, а також із правовими позиціями, викладених у низці рішень ЕСП $\lambda$.

ЕСП^ неодноразово розглядав заяви громадян різних країн, які вважали, що їх тримання у місці, обгородженому металевими прутами, 3 перекриттям із дроту, тобто у металевих « клітках» під час розгляду їх справи національними судами - 6 порушенням їхніх прав. Наприклад, в одній iз ключових справ щодо такого тримання підсудних - «Свинаренко та Сляднев проти Росії» від 17.07.2014 р., - Суд, розглядаючи питання щодо використання «металевої клітки» у залах судових засідань у державах-членах Ради Европи, встановив: «Тримання людини в металевій клітці під час судового процесу само по собі є образою людської гідності в порушення статті 3, враховуючи об'єктивно принизливу природу такого поводження, яка є несумісною iз стандартами цивілізованої поведінки, що $є$ провідною ознакою демократичного суспільства». Суд також у цьому рішенні вказав на те, що «металеві клітки» використовуються як стандартний захід безпеки стосовно підозрюваних або обвинувачених, які постають перед судом під час знаходження під вартою, у деяких державахчленах Ради Свропи, таких як Вірменія, Азербайджан, Грузія, Молдова та Україна. Деякі інші держави використовують “клітки” у цілях безпеки за певних обставин або в спеціальних судах. Наприклад, у Суді 3 тяжких злочинів в Албанії обвинувачений може бути поміщений на лаву, що оточена металевими дротами. У Сербії є одна зала судових засідань - у районній (центральній) в’язниці м. Белград - що є додатковою залою Верховного Суду в Белграді, де лава підсудних оточена металевими дротами та куленепробивним склом. У Франції деякі суди використовують скляні “огородження", які в поодиноких випадках зміцнюються металевими тросами та використовуються відповідно до рішення головуючого судді суду. У Латвї, хоча невелика кількість 
судів усе ще має металеві клітки, ця практика зникає. В Італії металеві клітки, які були встановлені в 1980-х роках для судових процесів над обвинуваченими у членстві в мафії чи терористичних групах, більше не використовуються» [5].

У рішенні «Іващенко проти України», яке було винесено 10 вересня 2020 року суд також зауважив на тому, що «тримання підсудних, навіть тих, щодо яких не було ухвалено обвинувальний вирок, у металевих клітках під час судових засідань вбачається стандартною процедурою в Україні» [2]. У цій справі ЄСП $\mathcal{A}$ посилався на рішення «Корбан проти України» від 4 липня 2019 року, у якому Суд раніше встановив порушення статті 3 Конвенції у зв язку з триманням Заявника у «металевій клітці під час судових засідань. Під час застосування цього заходу не було враховано наявність чи відсутність реальних ризиків для безпеки тих, хто знаходився в приміщенні, а також його об'єктивно принижуючий характер (з огляду на висвітлення процесу у національних і міжнародних 3МI)» [3].

Тому з метою відповідності норм щодо умов перебування підсудних у залі судового засідання в новий Кримінально-процесуальний кодекс були внесені положення, зокрема, згідно із п. 2 ст. 21 Перехідних положень зазначено: «у місячний строк $з$ дня опублікування цього Кодексу внести на розгляд Верховної Ради України пропозиції щодо приведення законодавчих актів у відповідність із цим Кодексом, у тому числі 3 метою забезпечення фінансування: заміни у судах загальної юрисдикції металевих загороджень, які відокремлюють підсудних від складу суду і присутніх громадян, на загородження із скла чи органічного скла» [14]. Проте варто зазначити про те, що Уповноважений Верховної Ради України 3 прав людини у Спеціальній доповіді Уповноваженого Верховної Ради України з прав людини від 11 листопада 2015 року за результатами пілотного моніторингу застосування нового Кримінально процесульного кодексу України судами м. Києва протягом 2014-2015 рр. зробив такі висновки: «Однак за відсутності фінансування вказана норма залишається невиконаною». Зокрема, дані моніторингу щодо умов перебування підозрюваних у місці проведення засідання (без урахування проведення відеоконференції) у відсотковому відношенні наступні: у металевій клітці - 48,8 \%; без будь-яких обмежень за столом сторони захисту - 30,1\%; без будь-яких обмежень у залі з публікою - 8,9 \%; на лаві чи стільці без кайданків, але під наглядом конвою - 8,3 \%. Наведені спостереження моніторів підтвердили, що ситуація в судах щодо перебування підсудних у металевих клітках абсолютно не змінилась. А отже, можна прогнозувати, що ще досить тривалий час Европейський суд 3 прав людини змушений буде констатувати порушення Україною статті 3 Конвенції. Тому Верховній Раді України, Кабінету Міністрів України, Державній судовій адміністрації України, Державній пенітенціарній службі України слід вжити заходів щодо приведення нормативних актів у відповідність з КПК України щодо умов перебування підозрюваного, обвинуваченого під час судового розгляду, у тому числі в частині забезпечення фінансування заміни в судах загальної юрисдикції металевих загороджень, які відокремлюють підсудних від складу суду і присутніх громадян, на загородження зі скла чи органічного скла [15].

Більше того, із заміною «металевих кліток» на скляні огородження, так звані «скляні бокси», виникло питання щодо їх відповідності правам людини, закріплених у Конвенції, оскільки вони досить обмежують здатність безперервного спілкування обвинуваченого із своїх адвокатом через те, що комунікація здійснюється тільки через значно малі отвори, кількість яких обмежена, у той час як у «скляному боксі» одночасно можуть перебувати декілька підсудних. Також тримання людей у таких боксах, навіть якщо й вони скляні, може вважатися порушенням статті 3 Конвенції [10]. Варто додати й про те, що 8 січня 2020 року громадянин Старовойт Віталій Петрович звернувся до Президента України з електронною петицією через спеціальний розділ веб-сайту Офіційного інтернет-представництва Президента України з таким змістом: «Щодо заборони поміщення під- 
озрюваних, обвинувачених (підсудних) або засуджених у захисні кабіни в залах судових засідань, а також використовувати інші конструкції (загородження зі спеціального захисного скла, металеві загородження, тощо), які перешкоджають зазначеним особам брати ефективну участь у розгляді їх справи та конфіденційному спілкуванню 3 адвокатом (захисником), з метою отримання професійної правничої допомоги» [8]. Проте ця петиція була підтримана тільки 50-ма голосам, що є не достатньою для того, щоб Президент розглянув їі, тому вона так i залишилася без опрацювання.

Щодо аналізу практики ЕСП розміщення підсудних у скляних клітках можна навести приклад рішення «Ярослав Бєлоусов проти Росії» від 4 жовтня 2016 року, у якій Суд зазначив, що «розміщення підсудних за скляними перегородками або в скляних кабінах саме по собі не виключає елементу приниження, достатнього для досягнення мінімального рівня жорстокості, як у випадку 3 металевими клітками. Цей рівень може бути досягнутий, однак, якщо враховувати обставини в цілому, призведе до їх страждання або труднощів, інтенсивність яких перевищує неминучий рівень страждань, властивий триманню під вартою». У той час як перебування заявника в переповненій скляній кабіні уже становить порушення ст.3 конвенції [7]. Ще одним прикладом можна навести справу «Гущін та Гаскаров проти Росії» від 25 лютого 2020 року, у якій Судом проголошено наступне: «Щодо заяви другого заявника про те, що розміщення у скляній кабіні спричинило йому труднощі у спілкуванні із своїм захисником - це може розглядатися як елемент, що сприяє його занепокоєнню та стражданню, але не досягає мінімального рівня жорстокості, щоб було порушення статті 3 Конвенції» [1].

Головною проблемою в Україні все ж виступає те, що не всі суди забезпечені скляними огорожами в залах судового засідання, більше того навіть у п.4 Інструкції 3 організації конвоювання та тримання в судах обвинувачених (підсудних) зазначено: «Дозволити використання стаціонарних металевих загороджень у за- лах судових засідань місць для тримання обвинувачених (підсудних), засуджених до повної їх заміни загородженням зі скла чи органічного скла» [11].

\section{Висновки і перспективи подальших досліджень}

Заміна металевих кліток на скляні викликає дискусії стосовно того, чи дійсно перебування підсудних у них не буде принижувати їх честь та гідність, з одного боку - виникають труднощі із спілкуванням 3 адвокатом, відчуття, ніби людина уже за гратами ще до винесення вироку, проте 3 іншого - все ж з цілях безпеки в деяких категоріях злочинів потрібно обвинувачених ізолювати від учасників судового процесу. ЕСП у своїх рішеннях дійшов до висновку, що тримання осіб у скляних камерах не буде порушенням статті 3 Конвенції за умови: якщо буде достатньо місця в цих камерах, а також тільки у випадках, якщо особа взята під варту i цього вимагають міри безпеки.

Тому у цій роботі схиляємось до висновків ЄСП щ щодо скляних камер, а саме допустимості їх використання у випадках, коли існує загроза їх небезпечної для інших поведінки, і те, що Україна все ж замінює «металеві клітки» на «скляні бокси» свідчить про те, що ми рухаємось у правильному напрямку, беручи до уваги рекомендації, висловлені у рішеннях ЕСП Проте через брак фінансування процес заміни камер є повільним,і не всі суди ними забезпечені, що означає, що до повної заміни усіх металевих кліток - до ЕСП будуть скаржитися на порушення статті 3 Конвенції щодо тримання в металевих камерах у залі судових засідань.

\section{入iтepaтypa}

1. Case of Gushchin and Gaskarov v.Russia ((Application no. 22581/15 and 28251/15): Judgment European Court of Human Rights, 25 February 2020. HUDOC/ European Court of Human Rights. URL: https:// $\underline{\text { laweuro.com/?p }=10391}$

2. Case of Ivashchenko v. Ukraine((Application no. 760/03): Judgment European Court of Human Rights, 26 July 
2012. HUDOC / European Court of Human Rights. URL: $\underline{\text { https://hudoc.echr.coe.int/eng\#\{ }}$ \%22itemid\%22:[\%22001-112481\%22]\}

3. Case of Korban v. Ukraine((Application no. 26744/16): Judgment European Court of Human Rights, 4 July 2019. HUDOC / European Court of Human Rights. URL: https://hudoc.echr.coe.int/ eng\#\{\%22fulltext\%22:[\%22\\%22CASE \%20 OF\%20KORBAN\%20v.\%20UKRAINE $\% 22 \%$ 22],\%22documentcollectionid2\%22:[\%22GRA NDCHAMBER $\% 22, \% 22 \mathrm{CHAMBER} \% 221, \% 22$ itemid\%22:[\%22001-194188\%22]\}

4. Case of Soering v. The United Kingdom((Application no. 14038/88): Judgment European Court of Human Rights, 7 July 1989. HUDOC / European Court of Human Rights. URL: https://hudoc.echr.coe.int/ eng\#\{\%22fulltext\%22:[\%22|\%22CASE \%20 OF\%20SOERING\%20v.\%20THE\%20 UNITED $\% 20 \mathrm{KINGDOM} \backslash \% 22 \% 22], \% 22 \mathrm{do}$ cumentcollectionid2\%22:[\%22GRANDCH AMBER\%22,\%22CHAMBER\%22],\%22item id\%22:[\%22001-57619\%22]\}

5. Case of Svinarenko and Slyadney v. Russia ((Application no. 32541/08 and 43441/08): Judgment European Court of Human Rights, 17 July 2014. HUDOC/ European Court of Human Rights. URL:https://hudoc.echr.coe.int/ eng\#\{\%22fulltext\%22:[\%22|\%22CASE\%20 OF\%20SVINARENKO\%20AND\%20SLYADNEV\%20v.\%20RUSSIA $\mid \% 22 \% 22], \% 22 \mathrm{~d}$ ocumentcollectionid 2\%22:[\%22GRANDCH AMBER\%22,\%22CHAMBER\%22],\%22item id\%22:[\%22001-145817\%22]\}

6. Case of Tomasi v. France ((Application no. 12580/87): Judgment European Court of Human Rights, 27 August 1992. HUDOC / European Court of Human Rights. URL: https://hudoc.echr.coe.int/ eng\#\{\%22fulltext\%22:[\%22TOMASI\%20 v. \%20FRANCE\%22],\%22 documentco llectionid2\%22:[\%22GRANDCHAMB ER\%22,\%22CHAMBER\%221,\%22item id\%22:[\%22001-57796\%22]\}

7. Case of Yaroslav Belousov v.Ukraine ((Application no 2653/13 and 60980/14): Judgment European Court of Human Rights, 4 October 2016. HUDOC / European Court of Human Rights. URL:https://hudoc.echr.coe.int/ eng\#\{\%22fulltext\%22:[\%22\\%22CASE\%20
OF\% 20YAROSLAV\%20BELOUSOV\%20 v.\%20RUSSIA $1 \% 22 \% 22], \% 22$ document collectionid 2\%22:[\%22GRANDCHAMB ER\%22,\%22CHAMBER\%221,\%22item id\%22:[\%22001-166937\%22]\}

8. Електронні петиції : Офіційне інтернет-представництво Президента України [Електронний ресурс]. URL: https://petition.president.gov.ua/help

9. Загальна декларація прав людини: Міжнародний документ від 10.12.1948№ 995_015 [Електронний ресурс] URL: $\quad$ https://zakon.rada.gov.ua/laws/ show/995 015\#Text

10. Ініціатива «модельні суди»: рекомендації щодо впровадження [Електронний ресурc] URL: https://www.slideshare.net/ pravotv/ss-174176305

11. Інструкція 3 організації конвоювання та тримання в судах обвинувачених (підсудних), засуджених за вимогою судів [Текст] [затв. наказом Міністерства внутрішніх справ України, Міністерства юстиції України, Верховного Суду України, Вищого спеціалізованого суду України 3 розгляду цивільних і кримінальних справ, Державної судової адміністрації України, Генеральної прокуратури України від 26.05 .2015 p. No613/785/5/30/29/67/68] // Офіційний вісник України.- 2015. - No 49. - С. 107. - Ст. 1589.

12. Конвенція про захист прав людини і основоположних свобод : 3 поправками, внесен. відповідно до положень Протоколів №№ 11 та 14 з Протоколами №№ $1,4,6$, 7, 12 та 13) // Право України. 2010. № 10.C. 215-233;

13. Конституція України, прийнята Верхов. Радою України 28.06.1996 р., №254к/96-ВР // Відом. Верхов. Ради України. - 1996. - №30. Ст.141.

14. Кримінальний процесуальний кодекс України від 13.04.2012p. // Відомості Верховної Ради України. - 2013. - № 9-10. - № 11-12. --№ 13. - Ст. 88 (зі змінами і доповненнями).

15. Спеціальна доповідь Уповноваженого Верховної Ради України з прав людини за результатами пілотного моніторингу застосування нового Кримінального процесуального кодексу України судами м. Києва - К.: «Арт-Дизайн», 2015. - 132 с. 


\begin{tabular}{|c|c|}
\hline & \\
\hline 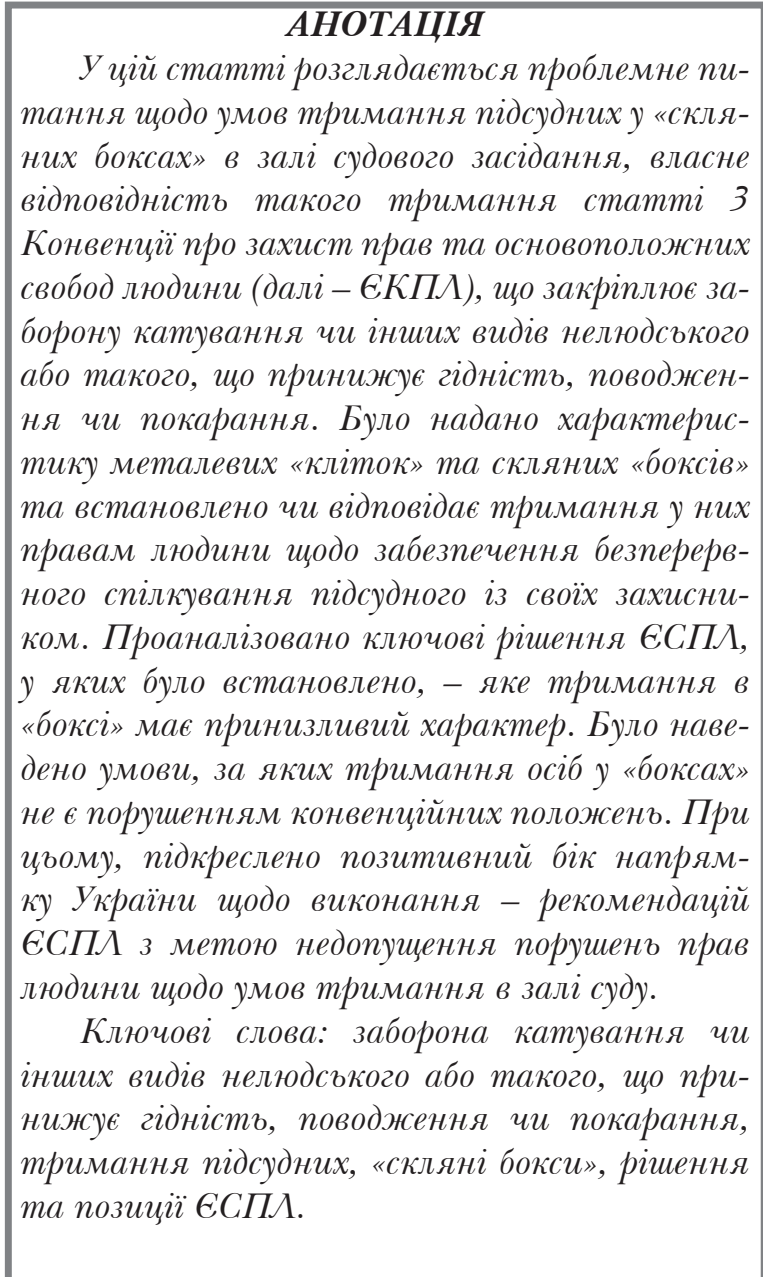 & $\begin{array}{l}\text { SUMMARY } \\
\text { This article deals with the problematic issue of } \\
\text { the conditions of detention of defendants in "glass } \\
\text { boxes» in the courtroom and the compliance of such } \\
\text { detention with Article } 3 \text { of the European Conven- } \\
\text { tion on Human Rights, which enshrines the prohi- } \\
\text { bition of cruel, inhuman or degrading treatment, } \\
\text { guilt or punishment. Characteristics of metal «cells» } \\
\text { and glass «boxes» were given and it was established } \\
\text { whether the detention in them meets the rights of } \\
\text { people to ensure continuous communication of the } \\
\text { defendant with his/her captor. A review of the key } \\
\text { decisions of the European Court of Human Rights } \\
\text { found that «box» is not justified in cases where there } \\
\text { are serious risks to the safety of people participating } \\
\text { in court proceedings and where alternative mea- } \\
\text { sures are insufficient. Provisions were made under } \\
\text { which the detention of persons in «boxes» would } \\
\text { not be in breach of the Convention. At the same } \\
\text { time, the positive side of Ukraine's approach to the } \\
\text { implementation of the European Court of Human } \\
\text { Rights recommendations in order to prevent viola- } \\
\text { tions of people's rights regarding the conditions of } \\
\text { detention in the courtroom was confirmed. } \\
\text { Keywords: prohibition of torture or other types } \\
\text { of inhuman or degrading, handling or punish- } \\
\text { ment, "glass boxes", conditions of detention, deci- } \\
\text { sions and positions of the European Court of Hu- } \\
\text { man Rights. }\end{array}$ \\
\hline
\end{tabular}

